\title{
II. MEASUREMENT OF CHEMICAL/PHYSICAL PROPERTIES
}

\author{
Alberto Lonardi, Consejo Nacional de Investigaciones, \\ Científicas y Técnicas and I.T.B.A., Buenos Aires, Argentina
}

\section{INTRODUCTION}

At all DSDP Leg 36 sites, direct and indirect measurements of the following physical parameters were made: water content, wet bulk density, porosity, sonic velocity, and acoustic impedance. These determinations were made at closely spaced intervals along the sedimentary column recovered near the top of the elevated unit of the Malvinas Plateau. ${ }^{1}$

This submarine province has been intensively studied during the past few years in its geological and geophysical aspects, mainly by Lamont-Doherty Geological Observatory expeditions in the South Atlantic, in an effort to better understand its relationship with the history and evolution of the Argentine Basin and, in a more general way, to study the opening of the South Atlantic Ocean. The density of data now available, including seismic reflection profiles and compressional velocities determined with the use of sonobuoys while reflection profiling, helped to select drilling sites which could render the highest scientific profile. As a byproduct of this effort, the direct measurement of physical properties of deep-seated sediments was intended to obtain models of the structure of the oceanic crust down to the maximum possible depth below the sea floor, which at present is about 1000 meters for present-day drilling capabilities, and to compare these determinations with those obtained in a very general way by theoretical estimates or by geophysical indirect methods.

\section{WATER CONTENT, POROSITY, AND WET BULK DENSITY (TABLE 1)}

Water content, porosity, and wet bulk density are determined onboard Glomar Challenger utilizing two different techniques, namely (1) gravimetric and volume techniques, and (2) gamma ray attenuation techniques. Although both methods are proven to be reasonably accurate and hence correlatable to each other when utilized in shore laboratories under no limitations of time of sampling procedures, experience gained in this and other cruises suggests that the sampling and measurement techniques used onboard can show relative discrepancies in excess of $15 \%$ if great care is not observed in every step taken during the sampling of the cores and in the measurements performed. In general, restrictions imposed on time by the

'Followed here is the use common in Argentine scientific literature of Malvinas Plateau. In English scientific literature, the name Falkland Plateau is used. drilling schedule and by the considerable number of samples to be processed by the available personnel imply that the resulting data will be relatively questionable. On the other hand, if the nature and expected accuracy of each single measurement have been properly registered and evaluated, this can result in a set of data very useful for general purposes and compatible for comparison with other physical properties in terms of trends and relative variability of the physical parameters involved.

An effort was made to obtain the maximum information possible on the in situ conditions of the unconsolidated and consolidated sediments and basement rocks recovered by drilling, but these conditions were in many cases impossible to attain, partly because drilling techniques currently utilized substantially modify many of the in situ physical properties. Some of those "disturbances" can be readily detected by visual observation, but others (for example, the effect of drilling in the modification of porosity of clays of low in situ water content) are more difficult to evaluate.

The centers of the cores are hopefully the areas of minimum disturbance and are, consequently, those from which the individual samples to be processed by the gravimetric methods were taken, except when additional samples were required, undisturbed or not, in order to support complementary data used for correction of the gamma ray attenuation technique. The relative induration of the sediments recovered determined the use of two different methods for gravimetric determinations, namely: the Syringe Technique, and the Rock "Chunk" Technique. The gravimetric techniques and salt corrections (Hamilton, 1959) are discussed in Boyce, 1973. The data processed during Leg 36 is presented here without salt corrections.

\section{Syringe Technique}

The Syringe Technique can only be used with soft sediments, normally those found in the upper section of the recovered sedimentary column. This simple technique allows determination of porosity, wet bulk density, and water content, and was normally performed immediately after the cores were split in halves for laboratory description and analysis. A calibrated 1cc syringe with the leading edge cut off and squared was inserted at selected points along the center of the split core sections. Samples were thus taken in a similar manner as piston cores in order to prevent disturbance of the sediments by laboratory sampling. By extruding the syringe and measuring the volumes of the wet samples and their wet and dry weights, water content 
TABLE 1

TABLE 1 - Continued

Gravimetric Measurements

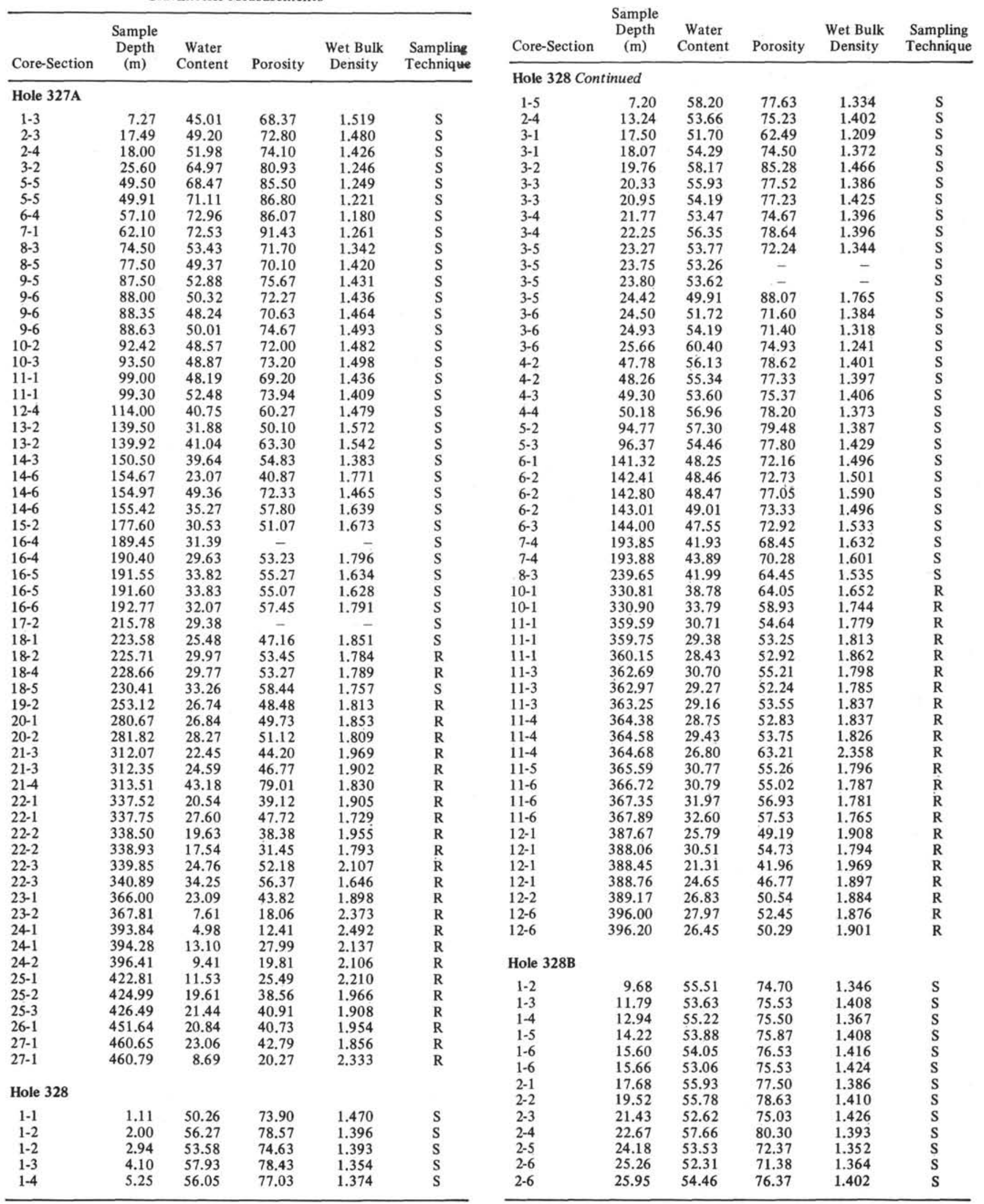


TABLE 1 - Continued

\begin{tabular}{|c|c|c|c|c|c|}
\hline Core-Section & $\begin{array}{c}\text { Sample } \\
\text { Depth } \\
\text { (m) }\end{array}$ & $\begin{array}{c}\text { Water } \\
\text { Content }\end{array}$ & Porosity & $\begin{array}{l}\text { Wet Bulk } \\
\text { Density }\end{array}$ & $\begin{array}{l}\text { Sampling } \\
\text { Technique }\end{array}$ \\
\hline
\end{tabular}

Hole 328B Continued

3-1 $\quad 27.65 \quad 54.06$

3-1 28.13

3-2 29.18

3-3 $\quad 30.75$

$\begin{array}{ll}3-4 & 32.16 \\ 3-5 & 33.40\end{array}$

3-6 $\quad 35.20$

3-6 $\quad 35.36$

$4-1 \quad 36.76$

4-1 36.80

$4-1$

4-2

4-5

$5-1$

5-1

$5-1$

5-1

5-3

$5-3$

$5-4$

$5-5$

5-5

5-6

6-2

6-3

6-4

6-5

6-6

$7-1$

$7-2$

$7-4$

$7-5$

$7-6$

$7-6$

37.10
38.83

41.18
42.98

46.40

46.80

46.96

47.21

48.16
49.30

50.07

50.75
52.27

53.07

53.84

55.81

57.28
58.68

60.28

61.75

63.21

435.68

437.58

439.67

441.36

$\begin{array}{ll}441.57 & 26.13\end{array}$

$443.17 \quad 28.98$

444.00

26.32

64.48

63.04

63.62

61.77

51.43

51.88

52.23

53.02
56.33

53.47
57.24

60.17

55.74
58.50

53.66

54.84
62.39

60.76

58.92
57.40

57.62

58.88
53.80

47.76

57.40

56.07
59.21

49.35

26.67

27.67

29.16
31.07

8.98
6.32

$80 . \overline{17}$

80.80

76.23

78.83

81.16

74.83

73.56

74.23

74.13

74.80

76.53

76.23

76.53

80.87

76.67

79.00

74.80

77.73

82.77

79.80

80.68

78.43

79.13

79.27

75.27

63.13

75.47

78.57

79.72

66.67

50.61
52.06

53.40

56.21

50.59

53.37

50.62

1.243

1.282

1.198

1.308

1.314

1.455

1.427

1.431

1.419

1.411
1.359

1.426

1.337

1.344

1.375

1.350
1.394

1.417

1.327

1.313

1.369

1.366

1.373

1.346

1.399

1.322

1.315

1.401

1.346

1.351

1.897

1.881

1.831

1.809

1.936

1.841

Hole 329

\begin{tabular}{rrrrrr}
$1-2$ & 2.38 & 36.11 & 60.03 & 1.662 & $\mathrm{~S}$ \\
$1-3$ & 3.59 & 54.46 & 75.23 & 1.381 & $\mathrm{~S}$ \\
$1-4$ & 5.32 & 59.40 & 78.90 & 1.328 & $\mathrm{~S}$ \\
$1-5$ & 7.17 & 64.82 & - & - & $\mathrm{S}$ \\
$1-6$ & 7.88 & 60.56 & 79.13 & 1.307 & $\mathrm{~S}$ \\
$2-1$ & 9.82 & 48.82 & 70.88 & 1.452 & $\mathrm{~S}$ \\
$2-3$ & 12.60 & 43.95 & 67.84 & 1.544 & $\mathrm{~S}$ \\
$2-4$ & 13.35 & 45.94 & 69.24 & 1.507 & $\mathrm{~S}$ \\
$2-4$ & 14.39 & 43.89 & 67.36 & 1.535 & $\mathrm{~S}$ \\
$2-5$ & 15.26 & 50.22 & - & - & $\mathrm{S}$ \\
$2-5$ & 15.30 & 43.05 & 66.83 & 1.552 & $\mathrm{~S}$ \\
$2-6$ & 16.33 & 43.07 & 66.95 & 1.555 & $\mathrm{~S}$ \\
$2-6$ & 16.89 & 49.18 & 75.36 & 1.532 & $\mathrm{~S}$ \\
$3-1$ & 18.60 & 49.60 & 71.20 & 1.436 & $\mathrm{~S}$ \\
$3-2$ & 20.62 & 49.69 & 71.10 & 1.431 & $\mathrm{~S}$ \\
$3-3$ & 21.50 & 53.13 & 73.87 & 1.390 & $\mathrm{~S}$ \\
$3-3$ & 22.13 & 56.55 & 75.93 & 1.343 & $\mathrm{~S}$ \\
$4-4$ & 32.80 & 56.84 & 65.93 & 1.160 & $\mathrm{~S}$ \\
$5-6$ & 44.83 & 56.60 & - & - & $\mathrm{S}$ \\
$7-4$ & 61.61 & 55.87 & 75.93 & 1.359 & $\mathrm{~S}$ \\
$8-5$ & 72.12 & 48.20 & 71.50 & 1.484 & $\mathrm{~S}$ \\
$8-5$ & 72.63 & 51.70 & - & - & $\mathrm{S}$ \\
$8-6$ & 74.32 & 58.05 & - & - & $\mathrm{S}$ \\
$9-4$ & 80.77 & 59.14 & 77.20 & 1.305 & $\mathrm{~S}$ \\
$10-1$ & 85.21 & 54.19 & 73.93 & 1.364 & $\mathrm{~S}$ \\
$10-4$ & 89.94 & 56.29 & 75.41 & 1.340 & $\mathrm{~S}$ \\
$10-5$ & 91.26 & 49.16 & 72.60 & 1.477 & $\mathrm{~S}$ \\
$10-5$ & 91.78 & 55.49 & - & - & $\mathrm{S}$ \\
$10-6$ & 93.01 & 48.11 & 71.10 & 1.478 & $\mathrm{~S}$ \\
\hline
\end{tabular}

TABLE 1 - Continued

\begin{tabular}{|c|c|c|c|c|c|}
\hline Core-Section & $\begin{array}{c}\text { Sample } \\
\text { Depth } \\
\text { (m) }\end{array}$ & $\begin{array}{c}\text { Water } \\
\text { Content }\end{array}$ & Porosity & $\begin{array}{c}\text { Wet Bulk } \\
\text { Density }\end{array}$ & $\begin{array}{l}\text { Sampling } \\
\text { Technique }\end{array}$ \\
\hline
\end{tabular}

Hole 329 Continued

11-1

11-2

11-3

11-4

11-6

$12-2$

$12-3$

$12-4$

$12-5$
$12-6$

13-1

13-2

13-3

13-4

13-5

13-6

14-1

14-3

14-4

$14-5$
$14-6$

14-6

15-3

15-4

16-5

$17-2$

$17-5$

18-2

18-4

18-5

19-1

$19-2$
$19-3$

19-3

19-4

20-1

20-2

20-3

20-4

20-4

20-5

20-6

20, CC

21-3

21-3

21-3

21-4

21-4

21-4

21-4

22-2

22-2

22-2

22-3

22-3

22-4

23-3

24-2

26-2

27-1

28-1

29-1

30-3

31-1

$32-4$

33-2

93.28
95.35
96.40
97.81
99.16
102.10
104.79
105.74
107.64
109.33

110.89
112.88

114.28

115.79

116.88

118.76
120.07

121.78

123.94
125.58

126.50

128.33

129.27

131.76
133.44

136.65

137.94

148.82

153.57
158.70

163.03

166.50

167.34

171.07

171.92

173.52

173.64

174.81

190.17

191.32

193.82

194.40

194.49

196.42

197.32

198.60

211.67

211.71

212.20

212.69

213.23
213.26

213.35

238.22

238.24

239.47

240.46

240.48
242.05

242.05
268.87

285.83

333.23

360.98

389.23

399.18

411.96

418.45

450.07

456.65

49.08

49.08

59.41
62.82

62.82
51.09

50.99

58.99

44.70

55.38

41.39

42.21

45.66

49.85

51.74 
TABLE 1 - Continued

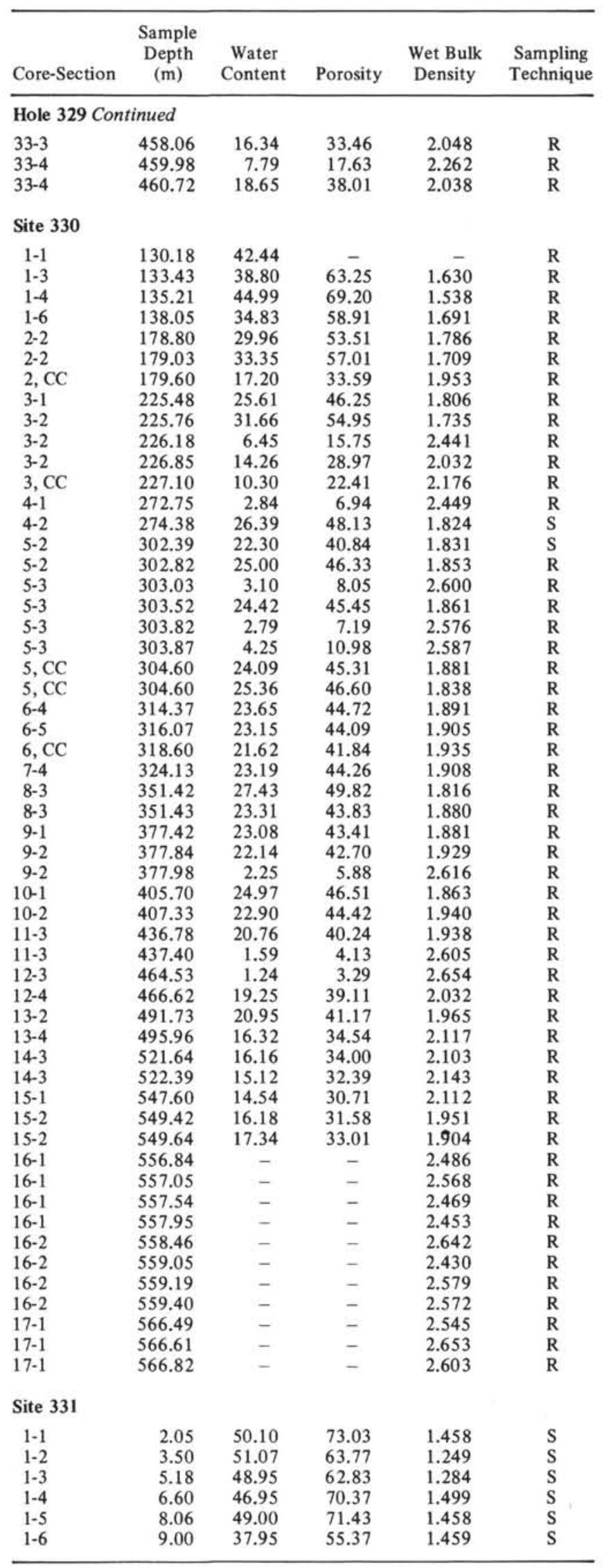

and porosity were calculated according to the following expressions (without salt corrections):

$$
\text { Wet water content }(\%)=\frac{\text { (weight evaporated water })}{(\text { weight wet sediment })} \times 100
$$

which is defined as the percent ratio between the weight of seawater in the sediment and the weight of the wet saturated sediment,

$$
\text { Porosity }(\%)=\frac{(100) \quad(\text { weight evaporated water })}{(1.0 \mathrm{~g} / \mathrm{cc}) \quad \text { (volume wet sediment) }}
$$

and is defined as the percent ratio between the volume of the void space within the sediment and the volume of the wet saturated sample.

$$
\text { Wet bulk density }(\mathrm{g} / \mathrm{cc})=\frac{\text { weight wet sediment }}{\text { volume wet sediment }}
$$

and is defined as the ratio between the weight of wet saturated sediments divided by its volume, and is expressed in $\mathrm{g} / \mathrm{cc}$.

It was found during the cruise that to minimize the inherent errors of this technique, the volume of sediments to be sampled with the syringe must be about $0.30 \mathrm{cc}$, but no less than $0.25 \mathrm{cc}$.

The weight of dry samples was determined in a precision balance after the extruded sediments were dried at $105^{\circ} \mathrm{C}$ for $24 \mathrm{hr}$ and placed in a dessicator to cool for 2 hr.

Weight measurements of samples, particularly when small, have limited accuracy, particularly less under rough sea conditions. Unfortunately, weighing of samples obtained at Hole $327 \mathrm{~A}$ was performed while sailing in heavy seas. It is estimated that errors in single weighing of samples amounted to about $7 \%$ to $10 \%$. Under normal conditions, however, an average error of $\pm 4 \%$ is expected when weighing small syringe samples.

\section{The Rock "Chunk" Technique}

This technique is utilized when the sediments recovered by drilling are too stiff to be sampled with a syringe. This is generally the case for the sediments recovered from the lower part of the sedimentary column. Samples of hard sediments and rocks were weighed wet and dry and their volumes determined by water displacement.

\section{Gamma Ray Attenuation Techniques (Table 2)}

Gamma Ray Attenuation Techniques are currently being used on a routine basis aboard Glomar Challenger and consist of passing the core immediately after recovery in its unsplit liner through the GRAPE apparatus (Gamma Ray Attenuation Porosity Evaluator). This equipment measures the intensity of a 3-mm-wide gamma ray passing through the sample. The output signal of the detector is processed and introduced into an analog recorder. The amplitude of the signal printed in the strip chart is linearly proportional to the bulk 
TABLE 2 2-min GRAPE

\begin{tabular}{|c|c|c|}
\hline Core-Section & $\begin{array}{l}\text { Sample } \\
\text { Depth } \\
\text { (m) }\end{array}$ & Density \\
\hline \multicolumn{3}{|l|}{ Hole 327A } \\
\hline $\begin{array}{l}20-1 \\
20-1 \\
20-2 \\
20-2 \\
20-2 \\
20-2 \\
21-2 \\
21-3 \\
21-3 \\
21-4 \\
22-1 \\
22-2 \\
22-3 \\
22-3 \\
22-3 \\
23-1 \\
23-1 \\
23-2 \\
23-2 \\
23-2 \\
23, C C \\
23, C C \\
24-1 \\
24-1 \\
24-1 \\
24-2 \\
24-2 \\
24-2 \\
24-2 \\
25-1 \\
25-2 \\
25-3 \\
26-1 \\
26-2 \\
27-1\end{array}$ & $\begin{array}{l}280.62 \\
280.62 \\
281.19 \\
281.19 \\
281.69 \\
281.69 \\
310.40 \\
311.25 \\
312.05 \\
313.50 \\
337.70 \\
338.85 \\
339.85 \\
340.25 \\
340.89 \\
366.00 \\
366.18 \\
366.77 \\
367.81 \\
367.85 \\
368.10 \\
368.10 \\
393.84 \\
394.09 \\
394.28 \\
395.25 \\
396.23 \\
396.40 \\
396.41 \\
422.81 \\
424.95 \\
426.46 \\
451.63 \\
453.34 \\
460.82\end{array}$ & $\begin{array}{l}1.900 \\
1.898 \\
1.908 \\
1.910 \\
1.975 \\
1.973 \\
1.886 \\
1.926 \\
2.006 \\
1.962 \\
1.801 \\
1.810 \\
1.714 \\
1.778 \\
1.775 \\
1.933 \\
1.954 \\
2.067 \\
2.699 \\
2.085 \\
1.894 \\
1.945 \\
2.541 \\
2.011 \\
2.160 \\
1.870 \\
1.775 \\
2.301 \\
2.428 \\
2.365 \\
2.119 \\
1.982 \\
1.976 \\
2.039 \\
2.313\end{array}$ \\
\hline \multicolumn{3}{|l|}{ Hole 328B } \\
\hline $\begin{array}{l}7-1 \\
7-1 \\
7-2 \\
7-2 \\
7-3 \\
7-4 \\
7-4 \\
7-5 \\
7-6 \\
7-6 \\
7, \mathrm{CC} \\
7, \mathrm{CC}\end{array}$ & $\begin{array}{l}435.68 \\
435.68 \\
437.58 \\
437.58 \\
439.67 \\
441.36 \\
441.36 \\
442.20 \\
443.17 \\
444.00 \\
444.60 \\
444.60\end{array}$ & $\begin{array}{l}1.885 \\
1.871 \\
1.857 \\
1.823 \\
1.826 \\
1.865 \\
1.858 \\
1.936 \\
1.842 \\
1.956 \\
1.981 \\
1.964\end{array}$ \\
\hline \multicolumn{3}{|l|}{ Site 329} \\
\hline $\begin{array}{l}20, C C \\
20, C C \\
22-2 \\
22-2 \\
22-2 \\
22-2 \\
22-2 \\
22-3 \\
22-3 \\
22-3 \\
22-4 \\
22-4 \\
23-1 \\
23-2\end{array}$ & $\begin{array}{l}198.60 \\
198.60 \\
238.22 \\
238.22 \\
239.45 \\
239.47 \\
239.47 \\
240.45 \\
240.46 \\
240.46 \\
242.05 \\
242.05 \\
266.40 \\
267.45\end{array}$ & $\begin{array}{l}1.679 \\
1.449 \\
1.340 \\
1.335 \\
1.406 \\
1.391 \\
1.384 \\
1.441 \\
1.307 \\
1.322 \\
1.432 \\
1.471 \\
1.853 \\
1.855\end{array}$ \\
\hline
\end{tabular}

TABLE 2 - Continued

\begin{tabular}{lrr}
\hline & $\begin{array}{c}\text { Sample } \\
\text { Depth }\end{array}$ \\
Core-Section & & Density \\
\hline Site 329 Cont. & & \\
$23-3$ & 268.15 & 1.669 \\
$23-3$ & 268.87 & 1.650 \\
$24-2$ & 285.83 & 1.669 \\
$24-2$ & 285.83 & 1.685 \\
$24-2$ & 285.90 & 1.872 \\
$24-3$ & 287.38 & 1.692 \\
$26-1$ & 332.35 & 1.507 \\
$26-2$ & 333.23 & 1.529 \\
$26-2$ & 333.23 & 1.554 \\
$26-2$ & 333.85 & 1.476 \\
$27-1$ & 360.98 & 1.663 \\
$27-1$ & 360.98 & 1.612 \\
$28-1$ & 389.23 & 1.760 \\
$28-1$ & 389.23 & 1.761 \\
$29-1$ & 399.18 & 1.839 \\
$29-1$ & 399.18 & 1.831 \\
$30-2$ & 409.54 & 1.969 \\
$30-3$ & 410.85 & 1.895 \\
$30-3$ & 411.96 & 1.884 \\
$30-3$ & 411.96 & 1.813 \\
$31-1$ & 418.45 & 2.251 \\
$31-1$ & 418.45 & 2.270 \\
$32-4$ & 450.70 & 2.110 \\
$32-4$ & 450.70 & 2.118 \\
$33-2$ & 456.65 & 2.033 \\
$33-2$ & 456.65 & 2.063 \\
$33-3$ & 458.06 & 2.095 \\
$33-3$ & 458.06 & 2.110 \\
$33-3$ & 458.22 & 2.354 \\
$33-4$ & 459.98 & 2.226 \\
$33-4$ & 459.98 & 2.277 \\
$33-4$ & 460.65 & 2.404 \\
$33-4$ & 460.72 & 2.084 \\
$33-4$ & 460.72 & 2.097 \\
& & \\
& & \\
& &
\end{tabular}

\section{Site 330}

\begin{tabular}{lll}
$1-1$ & 130.15 & 1.754 \\
$1-3$ & 133.43 & 1.716 \\
$1-4$ & 135.21 & 1.568 \\
$1-6$ & 138.05 & 1.694 \\
$1-6$ & 138.05 & 1.722 \\
$2-2$ & 178.80 & 1.803 \\
$2-2$ & 179.03 & 1.713 \\
$2, \mathrm{CC}$ & 179.60 & 2.660 \\
$2, \mathrm{CC}$ & 179.60 & 2.468 \\
$2, \mathrm{CC}$ & 179.60 & 3.130 \\
$3-1$ & 225.48 & 1.757 \\
$3-2$ & 225.76 & 1.650 \\
$3-2$ & 226.18 & 2.357 \\
$3-2$ & 226.18 & 2.438 \\
$3-2$ & 226.85 & 2.094 \\
$3, \mathrm{CC}$ & 227.10 & 2.005 \\
$3, \mathrm{CC}$ & 227.10 & 2.041 \\
$4-1$ & 273.05 & 3.434 \\
$4-1$ & 273.05 & 1.956 \\
$5-2$ & 302.82 & 1.894 \\
$5-2$ & 302.82 & 1.890 \\
$5-3$ & 303.03 & 2.694 \\
$5-3$ & 303.52 & 1.856 \\
$5-3$ & 303.82 & 2.692 \\
$5-3$ & 303.87 & 2.548 \\
$5-3$ & 303.87 & 2.492 \\
$5, \mathrm{CC}$ & 304.60 & 1.920 \\
$6-4$ & 314.37 & 1.929 \\
$6-5$ & 316.07 & 1.916 \\
$6, \mathrm{CC}$ & 318.60 & 1.947 \\
\hline & & \\
\hline & &
\end{tabular}


TABLE 2 - Continued

\begin{tabular}{|c|c|c|}
\hline Core-Section & $\begin{array}{c}\text { Sample } \\
\text { Depth } \\
\text { (m) }\end{array}$ & Density \\
\hline \multicolumn{3}{|l|}{ Site 330 Cont. } \\
\hline $7-4$ & 324.13 & 1.898 \\
\hline $8-3$ & 351.43 & 1.794 \\
\hline $8-3$ & 351.43 & 1.890 \\
\hline $9-1$ & 377.42 & 1.921 \\
\hline $9-2$ & 377.84 & 1.926 \\
\hline $9-2$ & 377.84 & 1.916 \\
\hline $9-2$ & 377.98 & 2.647 \\
\hline $10-2$ & 406.25 & 2.052 \\
\hline $10-2$ & 407.05 & 2.172 \\
\hline $10-2$ & 407.33 & 1.948 \\
\hline $11-2$ & 434.75 & 1.998 \\
\hline $11-3$ & 436.78 & 1.911 \\
\hline $11-3$ & 436.78 & 1.930 \\
\hline $11-3$ & 437.40 & 2.757 \\
\hline $11-5$ & 439.78 & 3.003 \\
\hline $12-3$ & 464.53 & 2.649 \\
\hline $12-4$ & 466.62 & 1.931 \\
\hline 13-1 & 490.85 & 2.142 \\
\hline $15-1$ & 547.25 & 2.090 \\
\hline $15-1$ & 547.60 & 2.097 \\
\hline $15-1$ & 548.11 & 2.118 \\
\hline $15-2$ & 548.73 & 2.060 \\
\hline $15-2$ & 549.42 & 1.860 \\
\hline $15-2$ & 549.42 & 1.831 \\
\hline $15-2$ & 549.49 & 1.844 \\
\hline $15-2$ & 549.64 & 1.672 \\
\hline $15, \mathrm{CC}$ & 550.10 & 2.705 \\
\hline $16-1$ & 556.50 & 2.457 \\
\hline $16-1$ & 556.50 & 2.380 \\
\hline $16-1$ & 556.50 & 2.401 \\
\hline $16-1$ & 556.60 & 2.568 \\
\hline $16-2$ & 558.00 & 2.649 \\
\hline $16-2$ & 558.00 & 2.406 \\
\hline $16-2$ & 558.00 & 2.528 \\
\hline $16-2$ & 558.00 & 2.627 \\
\hline $16-2$ & 559.20 & 2.636 \\
\hline $17-1$ & 566.00 & 2.516 \\
\hline $17-1$ & 566.00 & 2.659 \\
\hline $17-1$ & 566.00 & 2.588 \\
\hline $17-2$ & 567.50 & 2.674 \\
\hline $17-2$ & 568.40 & 2.470 \\
\hline $17-2$ & 568.95 & 2.550 \\
\hline $17-3$ & 569.71 & 2.538 \\
\hline $17, \mathrm{CC}$ & 570.60 & 2.678 \\
\hline
\end{tabular}

density of the sample, relative to reference standard signals used for calibration of the scale. The standards used for comparison consist of empty 2.6-in I.D. plastic liners and aluminum cylinders of 2.6 and 1.0 in. diameter which are run through the system before and after each set of measurements on sediments and rocks is performed.

When measuring unsplit samples in their liners, the portion of the core sampled moves across the gamma ray in about $2 \mathrm{sec}$. As a 2 -sec period has low precision, these routine data were used only as a basis for general correlation of physical parameters or when more precise measurements in hard sediments or rocks were not available. Otherwise, and in order to obtain more precise information on samples processed in conjunction with sonic compressional velocity measurements, individual samples were run for $2 \mathrm{~min}$, and later their water content measured to determine porosity in addition to bulk densities.
Although the GRAPE system is capable of measuring wet bulk density to about $\pm 10 \%$ for each 2 -sec counting period, the accuracy of the system is hampered by difficulties encountered in determining the real thickness of the sample exposed to the gamma ray. The analog GRAPE data are technically accurate when soft sediment completely fills the liner (although the sediment is probably disturbed). When stiff sediments or rocks are encountered, their diameters are smaller than the liners and therefore their diameters should be measured (although they are very rough and grooved). In addition, it must be noted whether they are surrounded by sediment, slurry, paste, water, or air. The sediment, slurry, or paste must have its density measured to make the proper adjustments. In addition, if the hard sediment or rock core is lying to one side of the liner, then the offset of the rock core's diameter from the axis of the gamma ray beam must also be measured (Boyce, 1973, 1976). If all of these parameters are measured, then it is possible to adjust the analog GRAPE data for stiff sediment and rocks for their actual gamma ray path length through the core samples. However the preceding parameters were inadvertently not measured during Leg 36, therefore hard rocks may have density errors ranging from $2 \%$ to $12 \%$. The average error for density can be on the order of $2 \%$ to $5 \%$ for misalignments of only $1 \mathrm{~mm}$ in samples with a diameter ranging from 6 to $2 \mathrm{~cm}$, respectively.

The analog GRAPE data $( \pm 11 \%)$ and 2 -min GRAPE data $( \pm 2 \%)$ were processed by equations in Boyce (1976), however, adjustments of the analog data for geometric problems were not made. Therefore, approximated "True" wet bulk density values were calculated from the Evans (1965) "corrected" wet bulk density values. The variables used in these equations are as follows: for sediments a true grain density of 2.60 $\mathrm{g} / \mathrm{cc}$, a "corrected" grain density of $2.60 \mathrm{~g} / \mathrm{cc}$, a true fluid density of $1.025 \mathrm{~g} / \mathrm{cc}$, and a "corrected" fluid density of $1.128 \mathrm{~g} / \mathrm{cc}$. These equations adjust for the anomalous fluid density of seawater and assume the grains have a quartz attenuation coefficient.

Standards of aluminum (true density $=2.71 \mathrm{~g} / \mathrm{cc}$ ) were used with both the analog GRAPE data and 2min GRAPE counts. For the analog data the $6.61-\mathrm{cm}$ aluminum standard was assigned a density value of 2.60 $\mathrm{g} / \mathrm{cc}$, and the $2.54 \mathrm{~cm}$ aluminum standard was assigned a value of $1.03 \mathrm{~g} / \mathrm{cc}$ as discussed in Boyce (1976). For the 2-min density data an attenuation coefficient for each sample was determined by a linear interpolation between $0.10432 \mathrm{~cm}^{2} / \mathrm{g}$ and $0.10838 \mathrm{~cm}^{2} / \mathrm{g}$ for 6.61 and $2.54 \mathrm{~cm}$ aluminum standards. This interpolation was made based on the thickness of the same, which is discussed in detail in Boyce (1976).

Leg 36 2-min techniques varied from Boyce (1976) where Leg 36 did not use a new air gamma count with every gamma count through the sample. This will result in an unusual statistical variation in any potential scatter diagram.

\section{SONIC COMPRESSIONAL VELOCITY} (TABLE 3)

In situ and laboratory determinations of sonic compressional velocities for marine sediments were started 
nearly $20 \mathrm{yr}$ ago (Laughton, 1954, 1957; Hamilton, 1956; Sutton et al., 1957). Since then, numerous observations of the velocity structure of the sea floor have been undertaken using indirect geophysical methods (seismic wide-angle reflection and refraction) in most regions of the world's oceans, and these data have been related to other mass physical properties of surface sediments (e.g., Nafe and Drake, 1957, 1963). However, it was not until the first deepsea drilling of the ocean was instrumented through the MOHOLE experiment (Guadalupe site), with samples retrieved and measured (Hamilton, 1969), that geologists and geophysicists had the opportunity to test earlier speculations on the nature and properties of deep-seated lithological units.

Because of the important role played by the knowledge of the velocity of sound through deep ocean sediments for its application in seismic reflection and refraction studies, future correlations, and predictions of the position of acoustic lithological units while drilling with regard to operational safety or for scientific reasons, compressional velocities will be always measured aboard Glomar Challenger in an effort to sample velocities of at least every major lithological unit downhole and to relate them with water content, bulk and grain density, carbon carbonate content, porosity, and X-ray mineralogy measurements in samples taken from the same intervals along the core.

The velocity of sound through soft and hard sediments and rocks was determined using a sound source operating at $400 \mathrm{kHz}$. Measurements were taken with the samples at atmospheric pressure and at temperatures ranging from $18^{\circ} \mathrm{C}$ to $25^{\circ} \mathrm{C}$ with a few sections measured at $15^{\circ} \mathrm{C}$.

The instruments used for measuring sonic velocity onboard Glomar Challenger during the cruise was the Hamilton frame system which was first utilized in 1970 during Leg 15 . The principle of operation is based on the accurate measurement of travel time of sound across the sediment or rock samples with simultaneous measurement of the travel distance involved. This is accomplished by placing the sample in close contact with a pair of transducers (one sending, the other receiving) after the best possible impedance matching has been achieved between sample and transducers. The difference between successive readings of a Dial Micrometer when the barium-titanite transducers are in close contact (relative "zero" distance) and when the sample is placed between the transducers is then recorded as the travel distance. Under favorable conditions (small ship vibrations and sea states 1 to 3 ), it was possible to obtain reliable readings close to $0.5 \mu \mathrm{m}$. The average thickness of the samples ranged between 2 and $4 \mathrm{~cm}$. The travel time across the sample is measured in a similar way by recording the differences between the relative travel time at zero separation of the transducers and the travel time of the pulse across the sample, as registered in a calibrated dial $(\mu \mathrm{sec})$ of the oscilloscope. The beginning of the wave train is aligned in both cases with the center vertical grid line of the scope face. Extreme care must be taken in measuring travel time, which in fact is the main source of error of the system, as it mainly depends on the proper alignment of the breaking point of the wave front which is often not sharp enough to be detected on weak signals. Thus, the measurement is affected by a subjective choice from among several possibilities.

Calibration of the time delay measurement system is often checked onboard, and eventual correction factors are taken into account when processing the data. During Leg 34 an exhaustive empirical check of the electronics was undertaken, by repetitive measurements performed on plexiglas and aluminum standards of known velocity, and the corrections so obtained were also used during Leg 36 . The corrections mentioned above are as follows:

\begin{tabular}{ccc}
\hline $\begin{array}{c}\mu \mathrm{sec} / \mathrm{cm} \\
\text { Scope Dial }\end{array}$ & Velocity Range & True Velocity \\
\hline 1.0 & all & Measured velocity $\times 1.0093$ \\
2.0 & $<3 \mathrm{~km} / \mathrm{sec}$ & Measured velocity $\times 1.011$ \\
& $>3 \mathrm{~km} / \mathrm{sec}$ & Measured velocity $\times 1.037$ \\
5.0 & $<3 \mathrm{~km} / \mathrm{sec}$ & Measured velocity $\times 0.988$ \\
& $>3 \mathrm{~km} / \mathrm{sec}$ & Measured velocity $\times 1.008$ \\
10.0 & $>3 \mathrm{~km} / \mathrm{sec}$ & Measured velocity $\times 0.991$ \\
& $<3 \mathrm{~km} / \mathrm{sec}$ & Measured velocity $\times 1.013$ \\
\hline
\end{tabular}

With the present system installed onboard it is possible, in most cases, to determine sonic velocities of soft and hard sediments and of rocks representative of every lithological unit encountered, provided the samples have been properly prepared. In a few cases, however, the level of the detected acoustic signal transmitted through the sample is too small to be measured with the present configuration or is just above the critical level. The sonic velocities so obtained are in gross error. This condition is found when there is a mismatch of the sample with the transducers (in perfect leveling of the sample faces and poor contact of the active surfaces), or more rarely so, for samples exhibiting physical properties of a particular nature (sediments gassy or rich in fossil plant debris, or with very low water content). In practice, particularly during periods of intensive coring, the time available does not permit successive corrective machining of each hard rock or consolidated sediment to obtain parallel faces and smooth surfaces. In other instances, hard sediments are brittle and successive scraping often destroys the sample. These limitations bear on the accuracy of only a certain percentage of the total sampling, but in many cases may include very old or basal sediments for which this information is highly desirable. If the present system is modified to increase its present maximum signal out of the sound source or the overall gain of the detected signal is increased, a general improvement in the accuracy and density of data is anticipated.

When the sediments were too soft to be handled out of the core liner, sonic velocities were measured by placing the longitudinally split core liner between the transducer pair. As the sound travels across two different media, thickness of the liner and travel time across it were calculated by measuring several sections of plastic liner independently, and the average values so determined were always subtracted from the thickness and travel time determined for the sediments measured in the liners, the corrections obtained were as follows: average liner thickness: $2.3 \mathrm{~mm}$, average time across the liner: $1.2 \mu \mathrm{sec}$. 
TABLE 3

Sonic Velocity

\begin{tabular}{|c|c|c|c|}
\hline $\begin{array}{l}\text { Core- } \\
\text { Section }\end{array}$ & $\begin{array}{c}\text { Sample } \\
\text { Depth } \\
\text { (m) }\end{array}$ & Velocity & Orientation $^{\mathrm{a}}$ \\
\hline $1-2$ & 5.78 & 1.722 & \\
\hline $1-3$ & 7.42 & 1.610 & \\
\hline $1-3$ & 7.51 & 1.614 & \\
\hline $1-3$ & 8.10 & 1.798 & \\
\hline $2-1$ & 14.48 & 1.579 & \\
\hline $2-2$ & 16.22 & 1.565 & \\
\hline $2-3$ & 17.01 & 1.847 & \\
\hline $2-4$ & 18.38 & 1.555 & \\
\hline $2-4$ & 18.38 & 1.576 & \\
\hline $2-4$ & 19.00 & 1.571 & \\
\hline $2-5$ & 19.98 & 1.573 & \\
\hline $2-5$ & 20.50 & 1.576 & \\
\hline $5-5$ & 49.50 & 1.537 & \\
\hline $6-4$ & 57.10 & 1.538 & \\
\hline $8-3$ & 74.50 & 1.524 & \\
\hline $9-6$ & 88.35 & 1.527 & \\
\hline $9-6$ & 88.80 & 1.530 & \\
\hline $9-6$ & 89.07 & 1.516 & \\
\hline $9-6$ & 89.07 & 1.532 & \\
\hline $10-1$ & 90.54 & 2.240 & \\
\hline $10-1$ & 90.54 & 2.186 & \\
\hline $10-1$ & 90.54 & 2.212 & \\
\hline $10-1$ & 90.88 & 2.265 & \\
\hline $10-1$ & 90.88 & 2.282 & \\
\hline $10-1$ & 90.88 & 2.263 & \\
\hline $10-3$ & 92.89 & 1.572 & \\
\hline $10-3$ & 93.50 & 1.557 & \\
\hline $11-1$ & 99.42 & 1.530 & \\
\hline $11-1$ & 99.42 & 1.536 & \\
\hline $11-1$ & 99.61 & 1.551 & \\
\hline $11-1$ & 100.15 & 4.127 & \\
\hline $11-1$ & 100.15 & 4.088 & \\
\hline $11-1$ & 100.15 & 4.138 & \\
\hline $11-1$ & 100.44 & 1.544 & \\
\hline $12-2$ & 110.15 & 1.560 & \\
\hline $12-2$ & 110.95 & 1.555 & \\
\hline $12-4$ & 113.30 & 1.575 & \\
\hline $12-4$ & 114.17 & 1.595 & \\
\hline $13-2$ & 139.48 & 1.630 & \\
\hline $13-2$ & 139.48 & 1.632 & \\
\hline $14-1$ & 147.74 & 1.580 & \\
\hline $14-1$ & 147.84 & 1.577 & \\
\hline $14-2$ & 148.58 & 1.589 & \\
\hline $14-2$ & 148.97 & 1.584 & \\
\hline $14-2$ & 148.97 & 1.588 & \\
\hline $14-3$ & 150.74 & 1.579 & \\
\hline $14-4$ & 152.18 & 1.600 & \\
\hline $14-5$ & 153.05 & 1.590 & \\
\hline $14-5$ & 153.05 & 1.594 & \\
\hline $14-6$ & 154.67 & 1.664 & \\
\hline $14-6$ & 154.97 & 1.628 & \\
\hline $14-6$ & 154.97 & 1.668 & \\
\hline $14-6$ & 155.42 & 1.669 & \\
\hline $14-6$ & 155.42 & 1.687 & \\
\hline $14-6$ & 155.42 & 1.671 & \\
\hline $15-2$ & 177.60 & 1.645 & \\
\hline $15-2$ & 177.20 & 1.645 & \\
\hline $16-1$ & 185.08 & 1.579 & \\
\hline $16-1$ & 185.60 & 1.629 & \\
\hline $16-1$ & 185.60 & 1.635 & \\
\hline $16-2$ & 186.49 & 1.680 & \\
\hline $16-2$ & 187.24 & 1.612 & \\
\hline $16-3$ & 188.05 & 1.698 & \\
\hline $16-3$ & 188.05 & 1.696 & \\
\hline $16-4$ & 189.55 & 1.612 & \\
\hline $16-5$ & 191.60 & 1.487 & \\
\hline
\end{tabular}

TABLE 3 - Continued

\begin{tabular}{|c|c|c|c|}
\hline $\begin{array}{l}\text { Core- } \\
\text { Section }\end{array}$ & $\begin{array}{l}\text { Sample } \\
\text { Depth } \\
\text { (m) }\end{array}$ & Velocity & Orientation $^{\mathrm{a}}$ \\
\hline $16-5$ & 191.60 & 1.630 & \\
\hline $16-6$ & 192.31 & 1.614 & \\
\hline $16-6$ & 192.75 & 1.706 & \\
\hline $17-2$ & 215.81 & 1.601 & \\
\hline $17-2$ & 215.81 & 1.613 & \\
\hline $18-1$ & 223.51 & 1.817 & \\
\hline $18-1$ & 223.51 & 1.827 & \\
\hline $18-1$ & 223.51 & 1.834 & \\
\hline $18-1$ & 223.51 & 1.827 & \\
\hline $18-1$ & 224.09 & 1.735 & \\
\hline $18-1$ & 224.09 & 1.724 & \\
\hline $18-1$ & 224.09 & 1.731 & \\
\hline $18-1$ & 224.09 & 1.731 & \\
\hline $18-2$ & 224.98 & 1.738 & \\
\hline $18-2$ & 224.98 & 1.751 & \\
\hline $18-2$ & 224.98 & 1.702 & \\
\hline $18-2$ & 225.59 & 1.721 & \\
\hline $18-3$ & 226.58 & 1.805 & \\
\hline $18-3$ & 226.58 & 1.822 & \\
\hline $18-4$ & 227.91 & 1.868 & \\
\hline $18-4$ & 227.91 & 1.844 & \\
\hline $18-4$ & 228.59 & 1.750 & \\
\hline $18-4$ & 228.59 & 1.807 & \\
\hline $18-4$ & 228.59 & 1.809 & \\
\hline $18-5$ & 229.20 & 1.763 & \\
\hline $18-5$ & 229.20 & 1.790 & \\
\hline $18-6$ & 231.32 & 1.851 & \\
\hline $18-6$ & 231.35 & 1.889 & \\
\hline $18-6$ & 231.32 & 1.852 & \\
\hline $18-6$ & $231: 32$ & 1.896 & \\
\hline $19-1$ & 251.88 & 1.748 & \\
\hline $19-1$ & 251.88 & 1.735 & \\
\hline $19-1$ & 251.88 & 1.736 & \\
\hline $19-2$ & 253.17 & 1.758 & \\
\hline $19-2$ & 253.17 & 1.749 & \\
\hline $19-2$ & 253.17 & 1.753 & \\
\hline $19-2$ & 253.17 & 1.736 & \\
\hline $19-2$ & 253.17 & 1.745 & \\
\hline $20-1$ & 280,70 & 1.850 & \\
\hline $20-1$ & 280.70 & 1.854 & \\
\hline $20-1$ & 280.70 & 1.864 & \\
\hline $20-1$ & 280.70 & 1.872 & \\
\hline $20-2$ & 281.72 & 1.836 & \\
\hline $20-2$ & 281.72 & 1.819 & \\
\hline $20-2$ & 281.72 & 1.818 & \\
\hline $20-2$ & 281.72 & 1.808 & \\
\hline $20-2$ & 281.72 & 1.813 & \\
\hline $21-2$ & 310.44 & 1.875 & \\
\hline $21-2$ & 310.44 & 1.894 & \\
\hline $21-2$ & 310.44 & 1.856 & \\
\hline $21-2$ & 310.44 & 1.859 & \\
\hline $21-2$ & 310.44 & 1.896 & \\
\hline $21-3$ & 312.06 & 1.975 & \\
\hline $21-3$ & 312.06 & 1.990 & \\
\hline $21-3$ & 312.06 & 1.964 & \\
\hline $21-3$ & 312.06 & 1.990 & \\
\hline $21-3$ & 312.06 & 1.959 & \\
\hline $21-3$ & 312.06 & 1.964 & \\
\hline $21-3$ & 312.29 & 1.867 & \\
\hline $21-3$ & 312.29 & 1.875 & \\
\hline $21-3$ & 312.29 & 1.880 & \\
\hline $21-3$ & 312.29 & 1.879 & \\
\hline $21-3$ & 312.29 & 1.886 & \\
\hline $21-3$ & 312.29 & 1.873 & \\
\hline $21-4$ & 313.42 & 1.859 & t. \\
\hline $21-4$ & 313.42 & 1.856 & \\
\hline $21-4$ & 313.42 & 1.832 & \\
\hline $21-4$ & 313.42 & 1.850 & \\
\hline
\end{tabular}


TABLE 3 - Continued

\begin{tabular}{|c|c|c|c|}
\hline $\begin{array}{l}\text { Core } \\
\text { Section }\end{array}$ & $\begin{array}{l}\text { Sample } \\
\text { Depth } \\
\text { (m) }\end{array}$ & Velocity & Orientation $^{\mathrm{a}}$ \\
\hline \multicolumn{4}{|c|}{ Hole 327A Continued } \\
\hline $21-4$ & 313.42 & 1.848 & \\
\hline $21-4$ & 313.42 & 1.837 & \\
\hline $22-1$ & 337.52 & 2.204 & \\
\hline $22-1$ & 337.52 & 2.244 & \\
\hline $22-1$ & 337.52 & 2.258 & \\
\hline $22-1$ & 337.52 & 2.276 & \\
\hline $22-1$ & 337.72 & 2.041 & \\
\hline $22-1$ & 337.72 & 2.001 & \\
\hline $22-1$ & 337.72 & 2.014 & \\
\hline $22-1$ & 337.72 & 2.021 & \\
\hline $22-2$ & 338.31 & 2.368 & \\
\hline $22-2$ & 338.31 & 2.368 & \\
\hline $22-2$ & 338.31 & 2.350 & \\
\hline $22-2$ & 338.31 & 2.372 & \\
\hline $22-2$ & 338.50 & 2.645 & \\
\hline $22-2$ & 338.50 & 2.644 & \\
\hline $22-2$ & 338.50 & 2.644 & \\
\hline $22-2$ & 338.93 & 2.784 & \\
\hline $22-2$ & 338.93 & 2.773 & \\
\hline $22-2$ & 338.92 & 2.794 & \\
\hline $22-3$ & 339.90 & 2.097 & \\
\hline $22-3$ & 339.90 & 2.114 & \\
\hline $22-3$ & 339.90 & 2.091 & \\
\hline $22-3$ & 339.90 & 2.117 & \\
\hline $22-3$ & 340.89 & 2.590 & \\
\hline $22-3$ & 340.89 & 2.552 & \\
\hline $22-3$ & 340.89 & 2.740 & \\
\hline $22-3$ & 340.89 & 2.671 & \\
\hline $22-3$ & 340.89 & 2.679 & \\
\hline $22-3$ & 340.89 & 2.609 & \\
\hline $23-1$ & 366.00 & $2.2 \% 6$ & \\
\hline $23-1$ & 366.00 & 2.283 & \\
\hline $23-1$ & 366.00 & 2.279 & \\
\hline $23-2$ & 367.70 & 2.305 & \\
\hline $23-2$ & 367.70 & 2.315 & \\
\hline $23-2$ & 367.81 & 4.421 & \\
\hline $23-2$ & 367.81 & 4.312 & \\
\hline $23-7$ & 374.00 & 2.278 & $\mathrm{H}$ \\
\hline $23-7$ & 374.00 & 2.252 & $\mathrm{H}$ \\
\hline $23-7$ & 374.00 & 2.278 & $\mathrm{H}$ \\
\hline $23-7$ & 374.00 & 2.249 & $\mathrm{H}$ \\
\hline $23-7$ & 374.00 & 2.127 & V \\
\hline $23-7$ & 374.00 & 2.136 & V \\
\hline $23-7$ & 374.00 & 2.151 & V \\
\hline $23-7$ & 374.00 & 2.120 & V \\
\hline $23-7$ & 374.00 & 2.101 & V \\
\hline $23-7$ & 374.00 & 2.114 & V \\
\hline $23-7$ & 374.00 & 2.112 & V \\
\hline $23-7$ & 374.00 & 2.108 & V \\
\hline $24-1$ & 393.84 & 3.893 & \\
\hline $24-1$ & 393.84 & 3.950 & \\
\hline $24-1$ & 393.84 & 3.838 & \\
\hline $24-1$ & 393.84 & 3.883 & \\
\hline $24-1$ & 394.28 & 2.761 & \\
\hline 24-1 & 394.28 & 2.736 & \\
\hline $24-2$ & 395.23 & 2.037 & \\
\hline $24-2$ & 395.23 & 2.011 & \\
\hline $24-2$ & 395.23 & 2.023 & \\
\hline $24-2$ & 396.22 & 1.893 & \\
\hline $24-2$ & 396.42 & 3.083 & \\
\hline $24-2$ & 396.42 & 3.484 & \\
\hline $24-2$ & 396.42 & 3.126 & \\
\hline $24-2$ & 397.42 & 3.403 & \\
\hline $24-2$ & 396.42 & 3.386 & \\
\hline $24-2$ & 396.42 & 3.236 & \\
\hline $24-2$ & 396.42 & 3.236 & \\
\hline $24-2$ & 396.42 & 3.088 & \\
\hline $25-1$ & 422.84 & 3.573 & \\
\hline $25-1$ & 422.84 & 3.674 & \\
\hline
\end{tabular}

TABLE 3 - Continued

\begin{tabular}{|c|c|c|c|}
\hline $\begin{array}{l}\text { Core } \\
\text { Section }\end{array}$ & $\begin{array}{l}\text { Sample } \\
\text { Depth } \\
\text { (m) }\end{array}$ & Velocity & Orientation $^{2}$ \\
\hline \multicolumn{4}{|c|}{ Hole 327A Continued } \\
\hline $25-1$ & 422.84 & 3.721 & \\
\hline $25-2$ & 424.95 & 2.273 & \\
\hline $25-2$ & 424.95 & 2.486 & \\
\hline $25-2$ & 424.95 & 2.251 & \\
\hline $25-3$ & 426.47 & 2.011 & \\
\hline $25-3$ & 426.47 & 2.040 & \\
\hline $25-3$ & 426.47 & 2.009 & \\
\hline $25-3$ & 426.47 & 1.999 & \\
\hline $26-1$ & 451.60 & 1.877 & \\
\hline $26-1$ & 451.60 & 1.876 & \\
\hline $26-1$ & 451.60 & 1.873 & \\
\hline $26-2$ & 453.34 & 1.847 & \\
\hline $26-2$ & 453.34 & 1.861 & \\
\hline $27-1$ & 460.75 & 2.963 & \\
\hline $27-1$ & 460.75 & 3.150 & \\
\hline $27-1$ & 460.75 & 3.084 & \\
\hline $27-1$ & 460.75 & 3.072 & \\
\hline
\end{tabular}

Hole 328

\begin{tabular}{rrr}
$1-1$ & 1.12 & 1.623 \\
$1-1$ & 1.22 & 1.611 \\
$1-1$ & 1.22 & 1.601 \\
$1-2$ & 2.00 & 1.520 \\
$1-2$ & 2.00 & 1.523 \\
$1-2$ & 2.88 & 1.592 \\
$1-3$ & 4.10 & 1.534 \\
$1-4$ & 5.24 & 1.509 \\
$1-5$ & 7.20 & 1.534 \\
$2-4$ & 13.24 & 1.540 \\
$2-4$ & 13.24 & 1.540 \\
$2-4$ & 13.24 & 1.536 \\
$3-1$ & 17.50 & 1.516 \\
$3-1$ & 18.07 & 1.504 \\
$3-2$ & 19.76 & 1.520 \\
$3-3$ & 20.33 & 1.507 \\
$3-3$ & 20.95 & 1.516 \\
$3-3$ & 20.95 & 1.522 \\
$3-4$ & 21.77 & 1.515 \\
$3-4$ & 21.77 & 1.519 \\
$3-4$ & 22.25 & 1.521 \\
$3-4$ & 22.25 & 1.522 \\
$3-5$ & 23.27 & 1.524 \\
$3-5$ & 23.75 & 1.539 \\
$3-5$ & 24.42 & 1.543 \\
$3-6$ & 24.93 & 1.561 \\
$3-6$ & 25.66 & 1.530 \\
$4-2$ & 47.78 & 1.493 \\
$4-2$ & 48.26 & 1.511 \\
$4-4$ & 50.18 & 1.520 \\
$5-2$ & 94.77 & 1.513 \\
$5-2$ & 95.40 & 1.505 \\
$5-3$ & 96.37 & 1.501 \\
$6-1$ & 141.32 & 1.540 \\
$6-1$ & 141.32 & 1.538 \\
$6-2$ & 142.41 & 1.539 \\
$6-2$ & 143.01 & 1.540 \\
$6-2$ & 143.01 & 1.542 \\
$6-3$ & 144.00 & 1.524 \\
$6-3$ & 144.00 & 1.525 \\
$7-4$ & 193.88 & 1.541 \\
$7-4$ & 193.88 & 1.548 \\
$9-7$ & 292.30 & 1.582 \\
$10-1$ & 330.81 & 1.580 \\
\hline & &
\end{tabular}


TABLE 3 - Continued

\begin{tabular}{|c|c|c|c|}
\hline $\begin{array}{l}\text { Core } \\
\text { Section }\end{array}$ & $\begin{array}{l}\text { Sample } \\
\text { Depth } \\
\text { (m) }\end{array}$ & Velocity & Orientation \\
\hline \multicolumn{4}{|c|}{ Hole 328 Continued } \\
\hline $10-1$ & 330.81 & 1.576 & \\
\hline $10-1$ & 330.81 & 1.560 & \\
\hline $10-1$ & 330.81 & 1.576 & \\
\hline $10-1$ & 330.81 & 1.560 & \\
\hline $10-1$ & 330.90 & 1.729 & \\
\hline $10-1$ & 330.90 & 1.721 & \\
\hline $10-7$ & 339.50 & 1.665 & \\
\hline $10-7$ & 339.50 & 1.697 & \\
\hline $11-1$ & 359.59 & 1.854 & \\
\hline $11-1$ & 359.59 & 1.846 & \\
\hline $11-1$ & 359.59 & 1.843 & \\
\hline $11-1$ & 359.75 & 1.846 & \\
\hline $11-1$ & 359.75 & 1.858 & \\
\hline $11-1$ & 359.75 & 1.824 & \\
\hline $11-1$ & 360.15 & 1.800 & \\
\hline $11-3$ & 362.68 & 1.673 & \\
\hline $11-3$ & 362.68 & 1.675 & \\
\hline $11-3$ & 362.97 & 1.753 & \\
\hline $11-3$ & 362.97 & 1.730 & \\
\hline $11-3$ & 363.95 & 1.750 & \\
\hline $11-3$ & 363.25 & 1.795 & \\
\hline $11-3$ & 363.25 & 1.789 & \\
\hline $11-3$ & 363.25 & 1.763 & \\
\hline $11-4$ & 363.60 & 1.688 & \\
\hline $11-4$ & 363.60 & 1.699 & \\
\hline $11-4$ & 364.38 & 1.837 & \\
\hline $11-4$ & 364.38 & 1.839 & \\
\hline $11-4$ & 364.58 & 1.721 & \\
\hline $11-4$ & 364.58 & 1.720 & \\
\hline $11-5$ & 365.59 & 1.706 & \\
\hline $11-5$ & 365.98 & 1.718 & \\
\hline $11-6$ & 366.72 & 1.673 & \\
\hline $11-6$ & 366.72 & 1.677 & \\
\hline $11-6$ & 367.35 & 1.691 & \\
\hline $11-6$ & 367.35 & 1.690 & \\
\hline $11-6$ & 367.89 & 1.699 & \\
\hline $12-1$ & 387.67 & 1.902 & \\
\hline $12-1$ & 388.06 & 1.923 & \\
\hline $12-1$ & 388.06 & 1.824 & \\
\hline $12-1$ & 388.45 & 1.965 & V \\
\hline $12-1$ & 388.45 & 1.985 & V \\
\hline $12-1$ & 388.45 & 2.148 & $\mathrm{H}$ \\
\hline $12-1$ & 388.45 & 2.151 & $\mathrm{H}$ \\
\hline $12-1$ & 388.45 & 2.126 & $\mathrm{H}$ \\
\hline $12-1$ & 388.76 & 1.941 & \\
\hline $12-1$ & 388.76 & 1.948 & \\
\hline $12-2$ & 389.17 & 1.833 & \\
\hline $12-2$ & 389.17 & 1.831 & \\
\hline $12-2$ & 389.17 & 1.822 & \\
\hline $12-2$ & 389.17 & 1.836 & \\
\hline $12-6$ & 396.00 & 1.787 & \\
\hline $12-6$ & 396.00 & 1.779 & \\
\hline $12-6$ & 396.20 & 1.825 & $\mathrm{H}$ \\
\hline $12-6$ & 396.20 & 1.825 & $\mathrm{H}$ \\
\hline $12-6$ & 396.20 & 1.822 & $\mathrm{H}$ \\
\hline $12-6$ & 396.20 & 1.745 & V \\
\hline $12-6$ & 396.20 & 1.732 & V \\
\hline $12-6$ & 396.20 & 1.735 & $\mathrm{~V}$ \\
\hline \multicolumn{4}{|c|}{ Hole 328B } \\
\hline $1-2$ & 9.68 & 1.539 & \\
\hline $1-2$ & 9.68 & 1.535 & \\
\hline $1-3$ & 11.23 & 1.540 & \\
\hline $1-3$ & 11.23 & 1.538 & \\
\hline $1-4$ & 12.94 & 1.547 & \\
\hline
\end{tabular}

TABLE 3 - Continued

\begin{tabular}{lccc}
\hline & Sample & & \\
Core & $\begin{array}{c}\text { Depth } \\
\text { Section }\end{array}$ & Velocity & Orientation \\
\hline
\end{tabular}

\section{Hole 328B Continued}

$$
1-4 \quad 12.94
$$

$\begin{array}{lll}1-5 & 14.25 & 1.517\end{array}$

$\begin{array}{lll}1-5 & 14.22 & 1.522\end{array}$

$\begin{array}{lll}1-6 & 15.66 & 1.528\end{array}$

$\begin{array}{lll}1-6 & 15.66 & 1.535\end{array}$

1-1 $\quad 8.80 \quad 1.576$

$1-1 \quad 8.80 \quad 1.612$

$\begin{array}{lll}2-1 & 17.68 & 1.522\end{array}$

$\begin{array}{lll}2-1 & 17.68 & 1.522\end{array}$

2-2 $\quad 19.52 \quad 1.530$

$\begin{array}{lll}2-2 & 19.52 & 1.523\end{array}$

$\begin{array}{lll}2-3 & 21.43 & 1.544\end{array}$

$\begin{array}{lll}2-3 & 21.43 & 1.544\end{array}$

$2-4 \quad 22.67=1.536$

$2-4 \quad 22.67 \quad 1.535$

$\begin{array}{lll}2-5 & 24.18 & 1.554\end{array}$

$\begin{array}{lll}2-5 & 24.18 & 1.554\end{array}$

$\begin{array}{lll}2-6 & 25.26 & 1.552\end{array}$

$\begin{array}{lll}2-6 & 25.26 & 1.559\end{array}$

$\begin{array}{lll}2-6 & 25.95 & 1.549\end{array}$

$\begin{array}{lll}2-6 & 25.95 & 1.551\end{array}$

$\begin{array}{lll}3-1 & 27.65 & 1.548\end{array}$

3-1 $27.65 \quad 1.553$

3-1 $28.13 \quad 1.538$

3-1 $28.13 \quad 1.536$

3-2 $29.18 \quad 1.552$

$\begin{array}{lll}3-2 & 29.18 & 1.549\end{array}$

$\begin{array}{lll}3-3 & 30.75 & 1.530\end{array}$

$\begin{array}{lll}3-3 & 30.75 & 1.535\end{array}$

$\begin{array}{lll}3-3 & 30.75 & 1.532\end{array}$

3-4 $32.16 \quad 1.531$

$\begin{array}{lll}3-4 & 32.16 & 1.536\end{array}$

$\begin{array}{lll}3-5 & 33.40 & 1.516\end{array}$

3-5 $\quad 33.40 \quad 1.525$

3-6 $35.20 \quad 1.942$

3-6 $35.20 \quad 1.952$

3-6 $35.36 \quad 1.925$

3-6 $\quad 35.36 \quad 1.957$

4-1 $\quad 36.76 \quad 1.510$

4-1 $\quad 36.76 \quad 1.506$

4-1 $\quad 37.10 \quad 1.513$

4-1 $\quad 37.10 \quad 1.503$

4-2 $\quad 38.83 \quad 1.510$

$\begin{array}{lll}4-2 & 38.83 & 1.505\end{array}$

4-4 $41.18 \quad 1.520$

4-4 $41.18 \quad 1.522$

$\begin{array}{lll}4-5 & 42.98 & 1.528\end{array}$

$\begin{array}{lll}4-5 & 42.98 & 1.525\end{array}$

5-1 $\quad 46.40 \quad 1.514$

5-1 $\quad 46.40 \quad 1.521$

5-1 $\quad 46.80 \quad 1.516$

$\begin{array}{lll}5-1 & 46.80 & 1.507\end{array}$

$\begin{array}{lll}5-1 & 47.21 & 1.514\end{array}$

$\begin{array}{lll}5-1 & 47.21 & 1.507\end{array}$

5-2 $48.16 \quad 1.506$

$\begin{array}{lll}5-2 & 48.16 & 1.510\end{array}$

$\begin{array}{lll}5-3 & 49.30 & 1.509\end{array}$

5-3 $49.30 \quad 1.515$

$\begin{array}{lll}5-3 & 50.07 & 1.510\end{array}$

$\begin{array}{lll}5-3 & 50.07 & 1.506\end{array}$

5-4 $\quad 50.75 \quad 1.516$

$\begin{array}{lll}5-4 & 50.75 & 1.514\end{array}$

$\begin{array}{lll}5-5 & 52.27 & 1.517\end{array}$

$\begin{array}{lll}5-5 & 52.27 & 1.512\end{array}$

$\begin{array}{lll}5-5 & 53.07 & 1.510\end{array}$

$\begin{array}{lll}5-6 & 53.84 & 1.518\end{array}$ 
TABLE 3 - Continued

\begin{tabular}{lccc}
\hline Core & $\begin{array}{c}\text { Sample } \\
\text { Depth } \\
(\mathrm{m})\end{array}$ & Velocity & Orientation \\
\hline
\end{tabular}

Hole 328B Continued

5-6 $\quad 53.84 \quad 1.516$

6-1 $\quad 55.81 \quad 1.517$

6-2 $\quad 57.28 \quad 1.509$

6-3 $58.68 \quad 1.503$

$\begin{array}{lll}6-4 & 60.28 & 1.503\end{array}$

6-5 $\quad 61.75 \quad 1.506$

$6-6 \quad 63.21 \quad 1.506$

6-6 $\quad 63.21 \quad 1.511$

$7-1 \quad 435.68 \quad 1.747$

$\begin{array}{lll}7-1 & 435.68 & 1.742\end{array}$

$\begin{array}{lll}7-2 & 437.58 & 1.747\end{array}$

$\begin{array}{lll}7-2 & 437.58 & 1.751\end{array}$

$\begin{array}{lll}7-3 & 439.67 & 1.730\end{array}$

$7-3 \quad 439.67 \quad 1.733$

$\begin{array}{lll}7-4 & 441.36 & 1.735\end{array}$

$7-5 \quad 441.57 \quad 1.918$

$\begin{array}{lll}7-5 & 441.57 & 1.919\end{array}$

$\begin{array}{lll}7-6 & 444.00 \quad 1.927\end{array}$

$\begin{array}{lll}7-6 & 444.00 & 1.927\end{array}$

$\begin{array}{lll}7-6 & 443.17 & 1.710\end{array}$

$\begin{array}{lll}7-7 & 444.50 & 1.783\end{array}$

$\begin{array}{lll}7-7 & 444.50 \quad 1.775\end{array}$

$\begin{array}{lll}7-7 & 444.50 & 1.807\end{array}$

$\begin{array}{lll}7-7 & 444.50 & 1.795\end{array}$

$\begin{array}{lll}7-7 & 444.50 & 1.810\end{array}$

$\begin{array}{lll}7-7 & 444.50 & 1.798\end{array}$

$\begin{array}{lll}7-7 & 444.50 \quad 1.806\end{array}$

$\begin{array}{lll}7-7 & 444.50 & 1.796\end{array}$

$\begin{array}{lll}7-7 & 444.50 & 1.822\end{array}$

$\begin{array}{lll}7-7 & 444.50 & 1.819\end{array}$

$\begin{array}{lll}7-7 & 444.50 & 1.808\end{array}$

$7-7 \quad 444.50 \quad 1.792$

$8-1 \quad 472.27 \quad 1.937$

$\begin{array}{lll}8-1 & 472.27 & 1.934\end{array}$

Site 329

\begin{tabular}{lrl}
$1-2$ & 2.38 & 1.694 \\
$1-3$ & 3.59 & 1.600 \\
$1-4$ & 4.81 & 1.553 \\
$1-5$ & 7.17 & 1.546 \\
$1-6$ & 7.88 & 1.551 \\
$2-1$ & 9.92 & 1.563 \\
$2-1$ & 9.92 & 1.568 \\
$2-3$ & 12.60 & 1.584 \\
$2-3$ & 12.60 & 1.541 \\
$2-4$ & 13.35 & 1.582 \\
$2-4$ & 13.35 & 1.575 \\
$2-4$ & 14.39 & 1.538 \\
$2-4$ & 14.39 & 1.433 \\
$2-5$ & 15.26 & 1.538 \\
$2-5$ & 15.26 & 1.544 \\
$2-5$ & 15.26 & 1.548 \\
$2-6$ & 16.33 & 1.549 \\
$2-6$ & 16.33 & 1.557 \\
$2-6$ & 16.89 & 1.536 \\
$3-1$ & 18.60 & 1.542 \\
$3-1$ & 18.60 & 1.546 \\
$3-2$ & 20.72 & 1.524 \\
$3-2$ & 20.72 & 1.535 \\
$3-3$ & 21.50 & 1.486 \\
$3-3$ & 21.50 & 1.492 \\
$3-3$ & 22.33 & 1.492 \\
$3-3$ & 22.13 & 1.497 \\
$3-3$ & 22.13 & 1.497 \\
$3-4$ & 23.13 & 1.460 \\
\hline
\end{tabular}

TABLE 3 - Continued

\begin{tabular}{|c|c|c|c|}
\hline $\begin{array}{l}\text { Core } \\
\text { Section }\end{array}$ & $\begin{array}{c}\text { Sample } \\
\text { Depth } \\
\text { (m) }\end{array}$ & Velocity & Orientation \\
\hline \multicolumn{4}{|c|}{ Site 329 Continued } \\
\hline $5-6$ & 44.83 & 1.549 & \\
\hline $5-6$ & 44.83 & 1.550 & \\
\hline $5-6$ & 44.83 & 1.552 & \\
\hline $5-6$ & 44.83 & 1.554 & \\
\hline $5-6$ & 44.83 & 1.551 & \\
\hline $8-5$ & 72.12 & 1.518 & \\
\hline $8-5$ & 72.12 & 1.520 & \\
\hline 8-6 & 74.32 & 1.552 & \\
\hline $8-6$ & 74.32 & 1.538 & \\
\hline $10-1$ & 85.21 & 1.534 & \\
\hline $10-1$ & 85.21 & 1.548 & \\
\hline $10-1$ & 85.21 & 1.535 & \\
\hline $10-4$ & 89.94 & 1.535 & \\
\hline $10-4$ & 89.94 & 1.535 & \\
\hline $10-5$ & 91.26 & 1.532 & \\
\hline $10-5$ & 91.26 & 1.535 & \\
\hline $10-6$ & 93.01 & 1.538 & \\
\hline $10-6$ & 93.01 & 1.529 & \\
\hline $11-1$ & 95.35 & 1.539 & \\
\hline $11-1$ & 95.35 & 1.541 & \\
\hline $11-2$ & 96.40 & 1.525 & \\
\hline $11-2$ & 96.40 & 1.538 & \\
\hline $11-3$ & 97.81 & 1.526 & \\
\hline $11-3$ & 97.81 & 1.531 & \\
\hline $11-4$ & 99.16 & 1.446 & \\
\hline $11-6$ & 102.10 & 1.536 & \\
\hline $12-1$ & 104.79 & 1.519 & \\
\hline $12-2$ & 105.74 & 1.536 & \\
\hline $12-2$ & 105.74 & 1.534 & \\
\hline $12-3$ & 107.64 & 1.534 & \\
\hline $12-4$ & 109.33 & 1.506 & \\
\hline $12-5$ & 110.89 & 1.536 & \\
\hline $12-6$ & 112.88 & 1.537 & \\
\hline $13-1$ & 114.28 & 1.537 & \\
\hline $13-2$ & 115.79 & 1.552 & \\
\hline $13-3$ & 116.88 & 1.537 & \\
\hline $13-4$ & 118.76 & 1.545 & \\
\hline $13-5$ & 120.07 & 1.545 & \\
\hline $13-6$ & 121.78 & 1.540 & \\
\hline $14-1$ & 123.94 & 1.546 & \\
\hline $14-2$ & 125.58 & 1.547 & \\
\hline $14-3$ & 126.50 & 1.558 & \\
\hline $14-4$ & 128.33 & 1.551 & \\
\hline $14-5$ & 129.27 & 1.543 & \\
\hline $14-6$ & 131.76 & 1.535 & \\
\hline $15-1$ & 133.44 & 1.517 & \\
\hline $15-2$ & 134.66 & 1.525 & \\
\hline $15-3$ & 136.65 & 1.522 & \\
\hline $15-4$ & 137.94 & 1.523 & \\
\hline $15-5$ & 139.28 & 1.522 & \\
\hline $15-6$ & 140.27 & 1.527 & \\
\hline $16-1$ & 142.86 & 1.536 & \\
\hline $16-2$ & 144.75 & 1.538 & \\
\hline $16-3$ & 145.64 & 1.533 & \\
\hline $16-4$ & 147.01 & 1.534 & \\
\hline $16-5$ & 148.82 & 1.524 & \\
\hline $16-6$ & 150.37 & 1.539 & \\
\hline $17-1$ & 152.25 & 1.533 & \\
\hline $17-2$ & 153.57 & 1.538 & \\
\hline $17-3$ & 154.98 & 1.533 & \\
\hline $17-4$ & 156.43 & 1.529 & \\
\hline $17-5$ & 158.70 & 1.533 & \\
\hline $17-6$ & 160.08 & 1.524 & \\
\hline $18-1$ & 161.38 & 1.531 & \\
\hline $18-2$ & 163.03 & 1.533 & \\
\hline
\end{tabular}


TABLE 3 - Continued

\begin{tabular}{|c|c|c|c|}
\hline & Sample & & \\
\hline $\begin{array}{l}\text { Core } \\
\text { Section }\end{array}$ & $\begin{array}{l}\text { Depth } \\
\text { (m) }\end{array}$ & Velocity & Orientation \\
\hline
\end{tabular}

\section{Site 329 Continued}

18-3 $164.42 \quad 1.531$

$\begin{array}{lll}18-4 & 165.93 & 1.530\end{array}$

$\begin{array}{lll}18-5 & 167.34 & 1.532\end{array}$

$\begin{array}{lll}18-6 & 169.63 & 1.533\end{array}$

$19-1 \quad 171.07 \quad 1.533$

$19-2 \quad 171.92 \quad 1.532$

$\begin{array}{lll}19-3 & 173.52 & 1.542\end{array}$

$19-4 \quad 174.81 \quad 1.534$

20-1 $\quad 190.17 \quad 1.550$

20-2 $191.32 \quad 1.541$

20-3 $193.82 \quad 1.533$

20-4 $194.43 \quad 1.553$

20-5 $196.42 \quad 1.546$

$20-6 \quad 197.32 \quad 1.543$

20-7 $198.50 \quad 1.520$

$\begin{array}{lll}20-7 & 198.50 & 1.520\end{array}$

$\begin{array}{lll}20-7 & 198.50 & 1.517\end{array}$

21-3 $212.20 \quad 1.543$

21-3 $211.71 \quad 1.551$

21-4 $212.69 \quad 1.540$

21-4 213.23 1.542

22-2 $239.47 \quad 1.551$

$22-3 \quad 240.46 \quad 1.589$

$\begin{array}{lll}22-3 & 240.46 \quad 1.593\end{array}$

$22-4 \quad 242.05 \quad 1.580$

22-2 238.22 1.605

$\begin{array}{lll}23-2 & 267.37 & 1.618\end{array}$

$\begin{array}{lll}23-2 & 267.37 & 1.587\end{array}$

23-2 $267.37 \quad 1.598$

24-2 $285.83 \quad 1.559$

24-2 $285.83 \quad 1.568$

24-2 $285.83 \quad 1.593$

24-2 $285.83 \quad 1.593$

26-2 $333.23 \quad 1.603$

26-2 $333.23 \quad 1.598$

$\begin{array}{lll}26-2 & 333.23 & 1.580\end{array}$

26-2 $333.23 \quad 1.592$

$\begin{array}{lll}27-1 & 360.98 & 1.654\end{array}$

27-1 $360.98 \quad 1.650$

$\begin{array}{lll}27-1 & 360.98 & 1.656\end{array}$

27-1 $360.98 \quad 1.661$

28-1 $389.23 \quad 1.708$

28-1 $389.23 \quad 1.703$

$28-1 \quad 389.23 \quad 1.662$

$28-1 \quad 389.23 \quad 1.663$

29-1 $399.18 \quad 1.708$

29-1 $399.18 \quad 1.730$

29-1 $\quad 399.18 \quad 1.730$

$\begin{array}{lll}29-1 & 399.18 & 1.756\end{array}$

$30-3 \quad 411.96 \quad 1.756$

$30-3 \quad 411.96 \quad 1.754$

$30-3 \quad 411.96 \quad 1.730$

30-3 411.96

$30-3 \quad 411.96$

30-3 411.96

31-1 418.45

$31-1 \quad 418.45$

31-1 418.45

$31-1 \quad 418.45$

31-1 418.45

$32-4 \quad 450.07$

32-4 450.07

$32-4 \quad 451.38$

32-4 451.38

$32-4 \quad 450.07$

$32-4$

450.07

1.727

1.748

4.071

4.128

4.102

3.746

3.716

2.174

2.192

2.072

2.086

2.198

V
$\mathrm{H}$
$\mathrm{H}$

TABLE 3 - Continued

\begin{tabular}{lccc}
\hline Core & $\begin{array}{c}\text { Sample } \\
\text { Depth } \\
\text { Section }\end{array}$ & Velocity & Orientation \\
\hline
\end{tabular}

Site 329 Continued

$\begin{array}{llll}33-2 & 456.65 & 2.224 & \mathrm{H} \\ 33-2 & 456.65 & 2.253 & \mathrm{H} \\ 33-2 & 456.65 & 2.172 & \mathrm{~V} \\ 33-2 & 456.65 & 2.159 & \mathrm{~V} \\ 33-3 & 458.06 & 2.240 & \mathrm{~V} \\ 33-3 & 458.06 & 2.240 & \mathrm{~V} \\ 33-3 & 458.24 & 2.241 & \mathrm{H} \\ 33-3 & 458.06 & 2.262 & \mathrm{H} \\ 33-4 & 459.98 & 3.385 & \mathrm{H} \\ 33-4 & 459.98 & 3.385 & \mathrm{H} \\ 33-4 & 459.98 & 2.065 & \mathrm{H} \\ 33-4 & 459.98 & 3.210 & \mathrm{~V} \\ 33-4 & 459.98 & 3.248 & \mathrm{~V} \\ 33-4 & 459.98 & 3.250 & \mathrm{~V} \\ 33-4 & 460.72 & 1.999 & \mathrm{~V} \\ 33-4 & 460.72 & 2.007 & \mathrm{~V} \\ 33-4 & 460.72 & 2.056 & \mathrm{H}\end{array}$

Site $\mathbf{3 3 0}$

$\begin{array}{llll}1-7 & 138.50 & 1.614 & \\ 1-1 & 130.18 & 1.654 & \\ 1-3 & 133.43 & 1.622 & \\ 1-4 & 135.21 & 1.583 & \\ 1-6 & 138.05 & 1.653 & \\ 2-2 & 178.80 & 1.715 & \\ 2-2 & 178.80 & 1.719 & \\ 2-2 & 179.03 & 1.698 & \\ 2-2 & 179.03 & 1.743 & \\ 2-2 & 179.03 & 1.753 & \\ 2-7 & 185.50 & 2.555 & \text { V } \\ 2-7 & 185.50 & 2.580 & \text { V } \\ 2-7 & 185.50 & 2.572 & \text { V } \\ 2-7 & 185.50 & 2.586 & \text { V } \\ 2-7 & 185.50 & 2.564 & \text { V }\end{array}$

$\begin{array}{lll}3-1 & 225.48 & 2.100\end{array}$

3-2 $225.76 \quad 1.943$

3-2 $225.76 \quad 1.944$

3-2 $226.18 \quad 3.685$

3-2 $226.18 \quad 3.709$

3-2 $226.85 \quad 3.062$

3-2 $226.85 \quad 3.107$

3.7 $\quad 233.00 \quad 2.623$

$\begin{array}{lll}3-7 & 233.00 & 2.623\end{array}$

$\begin{array}{lll}3-7 & 233.00 & 3.101\end{array}$

$\begin{array}{lll}3-7 & 233.00 & 3.093\end{array}$

4-1 $272.75 \quad 4.711$

4-1 $272.75 \quad 4.772$

4-1 $272.75 \quad 4.831$

$4-1 \quad 272.75 \quad 4.740$

4-1 $\quad 272.75 \quad 4.729$

4-1 $272.75 \quad 4.600$

4-1 $\quad 272.75 \quad 4.621$

4-1 $\quad 272.75 \quad 4.628$

4-1 $\quad 272.75 \quad 4.586$

4-1 $272.75 \quad 4.545$

4-1 $\quad 272.75 \quad 4.559$

$4-2 \quad 274.38 \quad 1.606$

4-2 $274.38 \quad 1.604$

$5-2 \quad 302.82 \quad 1.631$

$\begin{array}{lll}5-2 & 302.82 & 1.637\end{array}$

$5-2 \quad 302.82 \quad 1.731$

$5-2 \quad 302.82 \quad 1.733$

$\begin{array}{lll}5-3 & 303.87 & 3.953\end{array}$

$\begin{array}{lll}5-3 & 303.87 & 3.859\end{array}$

$5-3 \quad 303.82 \quad 4.914$

V
V
H
H
H
H
H
H
H
V
V
V
V
V
V


V
V
H
H


TABLE 3 - Continued

\begin{tabular}{|c|c|c|c|}
\hline $\begin{array}{l}\text { Core } \\
\text { Section }\end{array}$ & $\begin{array}{l}\text { Sample } \\
\text { Depth } \\
\text { (m) }\end{array}$ & Velocity & Orientation \\
\hline \multicolumn{4}{|c|}{ Site 330 Continued } \\
\hline $5-3$ & 303.82 & 5.015 & \\
\hline $5-3$ & 303.03 & 4.419 & \\
\hline $5-3$ & 303.03 & 4.467 & \\
\hline $5-3$ & 303.52 & 1.733 & \\
\hline $5-7$ & 309.00 & 1.781 & \\
\hline $6-4$ & 314.37 & 1.779 & $\mathrm{H}$ \\
\hline $6-4$ & 314.37 & 1.655 & V \\
\hline $6-7$ & 318.50 & 1.888 & \\
\hline $6-7$ & 318.50 & 1.867 & \\
\hline $6-5$ & 316.07 & 1.811 & \\
\hline $7-7$ & 328.00 & 1.696 & \\
\hline $7-4$ & 324.13 & 1.776 & \\
\hline $8-3$ & 351.42 & 1.825 & \\
\hline $9-1$ & 377.42 & 1.853 & \\
\hline $9-1$ & 377.42 & 1.853 & \\
\hline $9-2$ & 377.84 & 1.842 & \\
\hline $9-2$ & 377.84 & 1.838 & \\
\hline $9-2$ & 377.98 & 5.589 & \\
\hline $9-2$ & 377.98 & 4.858 & \\
\hline $9-2$ & 377.98 & 4.804 & \\
\hline $9-2$ & 377.98 & 5.418 & \\
\hline $9-2$ & 377.98 & 5.547 & \\
\hline $9-2$ & 377.98 & 5.002 & \\
\hline $10-1$ & 405.25 & 4.290 & \\
\hline $10-1$ & 405.25 & 4.310 & \\
\hline $10-1$ & 405.70 & 1.804 & \\
\hline $10-2$ & 407.33 & 1.885 & \\
\hline $10-2$ & 407.33 & 1.943 & \\
\hline $10-2$ & 406.20 & 1.890 & \\
\hline $11-1$ & 433.53 & 1.806 & \\
\hline $11-3$ & 436.78 & 2.463 & \\
\hline $11-3$ & 436.78 & 3.219 & \\
\hline $11-3$ & 436.78 & 2.534 & \\
\hline $11-3$ & 436.78 & 3.340 & \\
\hline $11-3$ & 436.78 & 1.749 & \\
\hline $11-3$ & 436.78 & 1.774 & \\
\hline $11-3$ & 437.40 & 5.221 & \\
\hline $11-3$ & 437.40 & 5.427 & \\
\hline $11-3$ & 437.40 & 5.434 & \\
\hline $11-6$ & 441.95 & 5.054 & \\
\hline $11-6$ & 441.95 & 5.086 & \\
\hline $11-6$ & 441.95 & 5.109 & \\
\hline $11-6$ & 441.95 & 5.137 & \\
\hline $11-6$ & 441.95 & 5.064 & \\
\hline $12-3$ & 465.01 & 1.809 & \\
\hline $12-4$ & 466.62 & 1.797 & \\
\hline $12-4$ & 466.62 & 1.828 & \\
\hline $12-3$ & 464.53 & 5.229 & \\
\hline $12-3$ & 464.53 & 5.256 & \\
\hline $12-7$ & 470.50 & 4.918 & \\
\hline $13-4$ & 495.96 & 1.836 & \\
\hline $13-4$ & 495.96 & 1.828 & \\
\hline $13-2$ & 491.73 & 1.743 & \\
\hline $13-2$ & 491.73 & 1.766 & \\
\hline $14-3$ & 521.64 & 1.830 & \\
\hline $14-3$ & 521.64 & 1.781 & \\
\hline $15-1$ & 547.60 & 2.044 & \\
\hline $15-1$ & 547.60 & 2.073 & \\
\hline $15-1$ & 547.60 & 2.099 & \\
\hline $15-1$ & 547.60 & 2.143 & \\
\hline $15-2$ & 549.64 & 1.977 & \\
\hline $15-7$ & 556.00 & 5.261 & \\
\hline $15-7$ & 556.00 & 5.261 & \\
\hline $15-7$ & 556.00 & 5.284 & \\
\hline $16-1$ & 556.50 & 5.490 & \\
\hline $16-1$ & 556.50 & 5.487 & \\
\hline
\end{tabular}

TABLE 3 - Continued

\begin{tabular}{|c|c|c|c|}
\hline $\begin{array}{l}\text { Core } \\
\text { Section }\end{array}$ & $\begin{array}{l}\text { Sample } \\
\text { Depth } \\
\text { (m) }\end{array}$ & Velocity & Orientation \\
\hline \multicolumn{4}{|c|}{ Site 330 Continued } \\
\hline $16-1$ & 556.80 & 4.195 & \\
\hline $16-1$ & 556.80 & 4.156 & \\
\hline $16-1$ & 556.80 & 4.172 & \\
\hline $16-1$ & 557.03 & 5.100 & \\
\hline $16-1$ & 557.03 & 5.280 & \\
\hline $16-1$ & 557.03 & 4.950 & \\
\hline $16-1$ & 557.50 & 3.977 & \\
\hline $16-1$ & 557.50 & 3.885 & \\
\hline $16-1$ & 557.50 & 4.007 & \\
\hline $16-1$ & 557.93 & 3.181 & \\
\hline $16-1$ & 557.93 & 3.155 & \\
\hline $16-1$ & 557.93 & 3.090 & \\
\hline $16-1$ & 557.50 & 4.186 & \\
\hline $16-1$ & 557.50 & 4.289 & \\
\hline $16-1$ & 557.50 & 4.371 & \\
\hline $16-1$ & 557.50 & 4.309 & \\
\hline $16-1$ & 557.50 & 3.961 & \\
\hline $16-1$ & 557.50 & 4.288 & \\
\hline $16-1$ & 557.50 & 4.287 & \\
\hline $16-1$ & 557.50 & 4.343 & \\
\hline $16-2$ & 559.03 & 2.443 & V \\
\hline $16-2$ & 559.03 & 2.498 & V \\
\hline $16-2$ & 559.03 & 2.406 & V \\
\hline $16-2$ & 559.45 & 2.817 & V \\
\hline $16-2$ & 559.45 & 4.763 & V \\
\hline $16-2$ & 559.45 & 4.817 & V \\
\hline $16-2$ & 559.45 & 4.952 & V \\
\hline $16-2$ & 559.50 & 5.350 & \\
\hline $16-2$ & 558.43 & 5.052 & \\
\hline $16-2$ & 558.43 & 5.272 & \\
\hline $16-2$ & 558.43 & 5.151 & \\
\hline $16-2$ & 559.16 & 3.653 & \\
\hline $16-2$ & 559.16 & 3.831 & \\
\hline $16-2$ & 559.16 & 3.538 & \\
\hline $16-2$ & 559.36 & 4.282 & \\
\hline $16-2$ & 559.36 & 4.236 & \\
\hline $16-2$ & 559.36 & 4.175 & \\
\hline $16-2$ & 559.45 & 5.285 & \\
\hline $16-2$ & 559.45 & 5.306 & \\
\hline $16-2$ & 559.45 & 5.278 & \\
\hline $16-2$ & 559.45 & 5.336 & \\
\hline $16-2$ & 559.45 & 5.304 & \\
\hline $16-2$ & 559.45 & 5.314 & \\
\hline $16-2$ & 559.45 & 5.352 & \\
\hline $17-1$ & 566.45 & 4.512 & \\
\hline $17-1$ & 566.45 & 4.122 & \\
\hline $17-1$ & 566.45 & 4.387 & \\
\hline $17-1$ & 566.79 & 4.850 & \\
\hline $17-1$ & 566.79 & 5.015 & \\
\hline $17-1$ & 566.79 & 5.019 & \\
\hline $17-1$ & 566.58 & 4.451 & \\
\hline $17-1$ & 566.58 & 4.845 & \\
\hline $17-1$ & 566.58 & 4.893 & \\
\hline $17-1$ & 566.58 & 4.785 & \\
\hline $17-1$ & 566.79 & 5.351 & \\
\hline $17-1$ & 566.79 & 5.001 & \\
\hline $17-1$ & 566.79 & 4.956 & \\
\hline $17-1$ & 566.79 & 5.238 & \\
\hline $17-1$ & 566.79 & 5.233 & \\
\hline $17-1$ & 566.79 & 5.224 & \\
\hline $17-1$ & 566.79 & 5.222 & \\
\hline $17-2$ & 567.59 & 5.162 & \\
\hline $17-2$ & 567.59 & 5.489 & \\
\hline $17-2$ & 567.59 & 5.313 & \\
\hline $17-2$ & 567.59 & 5.269 & \\
\hline $17-2$ & 567.88 & 4.748 & \\
\hline
\end{tabular}


TABLE 3 - Continued

\begin{tabular}{|c|c|c|c|}
\hline $\begin{array}{l}\text { Core } \\
\text { Section }\end{array}$ & $\begin{array}{l}\text { Sample } \\
\text { Depth } \\
\text { (m) }\end{array}$ & Velocity & Orientation \\
\hline \multicolumn{4}{|c|}{ Site 330 Continued } \\
\hline $17-2$ & 567.88 & 4.791 & \\
\hline $17-2$ & 567.88 & 4.793 & \\
\hline $17-2$ & 567.88 & 4.750 & \\
\hline $17-2$ & 567.88 & 4.416 & \\
\hline $17-2$ & 567.88 & 4.511 & \\
\hline $17-2$ & 567.88 & 4.484 & \\
\hline $17-3$ & 569.91 & 5.750 & \\
\hline $17-3$ & 569.91 & 5.679 & \\
\hline $17-3$ & 569.91 & 5.806 & \\
\hline $17-3$ & 569.91 & 5.709 & \\
\hline $17-3$ & 569.91 & 5.702 & \\
\hline $17-3$ & 569.91 & 5.680 & \\
\hline $17-7$ & 575.00 & 5.679 & \\
\hline $17-7$ & 575.00 & 5.613 & \\
\hline $17-7$ & 575.00 & 5.687 & \\
\hline $17-7$ & 575.00 & 5.684 & \\
\hline $17-7$ & 575.00 & 5.669 & \\
\hline $17-7$ & 575.00 & 5.648 & \\
\hline $17-7$ & 575.00 & 5.628 & \\
\hline
\end{tabular}

Site 331

$\begin{array}{lll}1-1 & 2.05 & 1.538 \\ 1-1 & 2.05 & 1.552 \\ 1-2 & 3.50 & 1.536 \\ 1-3 & 5.18 & 1.549 \\ 1-3 & 5.18 & 1.549 \\ 1-4 & 6.60 & 1.560 \\ 1-5 & 8.06 & 1.545 \\ 1-6 & 9.00 & 1.587 \\ 1-6 & 9.00 & 1.550 \\ 1-6 & 9.00 & 1.583 \\ 1-6 & 9.00 & 1.548\end{array}$

${ }^{\mathrm{a}}$ Core orientation during velocity measurement was almost always horizontal (i.e., parallel to bedding). In this column, however, the appropriate symbol $(\mathrm{H})$ is only shown when vertical measurements (V) were also made on the same sample, or when more than one horizontal measurement was made on the same sample.

Thicknesses of the liners available onboard varied by as much as $20 \%$. By adopting an average liner thickness, the error introduced in measuring sonic velocities for the velocity range of soft sediments is less than $0.8 \%$. In addition to the above-mentioned source of error, the effects of subjective alignment of the wave front used to measure travel times and the overall accuracy and precision of the Hamilton frame velocimeter on good samples is about $2 \%$ to $3 \%$.

\section{ACKNOWLEDGMENT}

Mr. R.E. Boyce (SIO) provided helpful review and discussion of the manuscript.

\section{REFERENCES}

Boyce, R.E., 1973. Physical properties-methods. In Edgar, N.T., Saunders, J.B., et al., Initial Reports of the Deep Sea Drilling Project, Volume 15: Washington (U.S. Government Printing Office), p. 1067

1976. Appendix I: Definitions and laboratory techniques of compressional sound velocity parameters by gravimetric and Gamma Ray Attenuation Technique. In Schlanger, S.O., Jackson, E.D., et al., Initial Reports of the Deep Sea Drilling Project, Volume 33: Washington (U.S. Government Printing Office), p. 931-958.

Evans, H.B., 1965. GRAPE-A Device for continuous determination of material density and porosity: SPWIA Logging Symp., 6th Ann., Dallas, Texas. Trans. v. 2, p. B1B25.

Hamilton, E.L., 1956. Low sound velocities in high porosity sediments: J. Acoust. Soc. Am., v. 28, p. 16.

1969. Sound velocity, elasticity, and related properties of marine sediments, North Pacific: II prediction of in situ properties: Naval Undersea Research and Development Center, San Diego, California, p. 145.

Laughton, A.S., 1954. Laboratory measurements of seismic velocities in ocean sediments: Proc. Roy. Soc. (London), Ser. A, v. 222, p. 336. 1957. Sound propagation in compacted ocean sediments: Geophysics, v. 22, p. 233.

Nafe, J.E. and Drake, C.L., 1957. Variation with depth in shallow and deep water marine sediments of porosity, density and the velocities of compressional and shear waves: Geophysics, v. 22, p. 523.

1963. Physical properties of marine sediments. In Hill, M.N. (Ed.), the Sea, v. 3: New York (Interscience Publishers), p. 794-815.

Sutton, G.H., Berckheimer, H., and Nafe, J.E., 1957. Physical analysis of deep sea sediments: Geophysics, v. 22, p. 779. 